\title{
Response size of Digestive organs of Broiler that are fed containing Jack bean (Canavalia ensiformis) different levels of protein with protease enzyme supplementation
}

\author{
Brahmadhita Pratama Mahardhika, Muhammad Ridla*, Rita Mutia, Miftakhun Naja \\ Study Program Nutrition and Feed Technology, Department of Nutrition and Feed \\ Technology, Faculty of Animal Science IPB University \\ 16680, Bogor, Indonesia
}

Submitted: 10 July 2020, Accepted: 21 July 2021

\begin{abstract}
This research was conducted to evaluate the use of Jack bean (Canavalia ensiformis), the level of protein diet, and the supplementation of protease enzymes to the size response of the starter phase of Broiler chicken digestive organs. Birds used in this study were 48 broilers of male chickens which were distributed into 3 observation factors and 3 replications (each replication consisted of 2 samples). The observation factor is Factor 1 are ingredients (basal diet based on soybean meal and a diet containing Jack bean), the second factor is the level of protein (22\% and $19.5 \%)$ and the third factor is enzyme treatment (without enzymes and the addition of proteases). The design used was a completely randomized factorial design (RALF) and analysis of variance. The results showed that the decrease in protein level (from $22 \%$ to $19.5 \%$ ) significantly high ( $\mathrm{P}<.0 .01$ ) increased the length of the jejunum but could be reduced to produce the same length as basal feed (PK 22\%) with the addition of the protease enzyme. The use of Jack bean significantly $(\mathrm{P}<0.05)$ increases the length of the jejunum but is reduced by the addition of the protease enzyme to the same as the basal diet produced by soybean meal. The addition of protease enzymes significantly reduced ileum weight and total small intestine weight $(\mathrm{P}<0.05)$ and significantly decreased jejunum length $(\mathrm{P}<0.01)$. There was no interaction between ingredient, level of protein, and protease enzymes on size response of digestibility broiler organ.
\end{abstract}

Keywords: Broiler; Digestive organ; Jack bean; Protease enzyme

*Corresponding Author: hmridla@yahoo.com 


\section{INTRODUCTION}

Feed is an important component for livestock especially poultry. Livestock health is influenced by feed provision to maintain or increase production. However, good quality feed must be provided to livestock. Quality feed is not only about the nutrient content, but also the digestibility. High nutrient feed but has unbalanced digestibility will result in waste.

The more undigested or disposed of through feces, the less efficient. Broiler chicken that is fed with low digestibility feed will increase their feed consumption to meet their needs (Mahardhika et al. 2020). Poultry feed contains maize as an energy source and soybean meal as an animal protein source. However, Indonesia is not a large-scale soybean oil producer, therefore soybean meal as a byproduct of the soybean oil industry is always imported. In 2016, Indonesia imported 1994.3 million tons of soybean (Ministry of Trade, 2017). This can be solved by exploring local feed ingredients to reduce the use of soybean meal. One of the materials is jack bean (Canavalia ensiformis). Jack bean (Canavalia ensiformis) has a white shell. The nutrient content of jack bean is good for poultry feed. Jack bean has $29.8 \%$ crude protein, $4.20 \%$ crude fat, $7.37 \%$ crude fiber, and $4.48 \%$ ash content (Doss et al., 2011). A high jack bean amount is not recommended because it has a $9.34 \mathrm{mg} / \mathrm{g}$ trypsin inhibitor (Mahardhika et $a l ., 2020)$. Thus, the trypsin needs to be reduced. According to Mahardhika et al. (2020), to reduce the trypsin to $7.96 \mathrm{mg} / \mathrm{g}$, it is treated at $26^{\circ} \mathrm{C}$ and 1 atm pressure for 25 minutes. Various attempts have been made to improve the poultry feed quality.

The feed digestibility problems can be solved by enzyme supplementation. The use of protease enzyme in $7 \%$ jack bean feed was able to improve the performance of starter phase broilers. In addition, the protease enzyme can improve metabolic energy and the performance of starter broilers with low protein feed (19.5\%) to produce metabolic energy and performance equal to the standard protein level required (22\%) (Mahardhika et al., 2020). It is necessary to evaluate the use of jack bean and protease enzymes in the health profile of the starter broiler diet. One of the parameters to measure the quality and effectiveness of feed is the response of digestive organ size. Good quality feed will not enlarge the digestive tract as a result of overwork in digesting feed. Maradon et al. (2015) explained that the slow digestive process allows enzymes to work longer in hydrolyzing nutrients so that the absorption of nutrient substances is ineffective. The activity of the digestive organs will increase if there is an increase in its capacity. Resnawati (2002) stated that the growth of internal organs has a positive correlation with chicken growth. The purpose of this study was to evaluate the use of jack bean, the level of diet protein, and the supplementation of protease enzymes on the digestive organ size of starter phase broilers. Animal

This study used male broiler strains of the Lohmann MB 202 starter phase which had previously been raised since Day Old Chick (DOC). This study used 48 broilers which were distributed into 3 observation factors and 3 replications (each replication consisted of 2 samples). The first observed factor was the material (basal diet based on soybean meal and jack bean), the second factor was the protein level $(22 \%$ and $19.5 \%$ ), and the third factor was the enzyme treatment (without enzymes and the addition of protease).

\section{Diet}

The pre-starter phase used $23 \%$ PK and EM $3000 \mathrm{Kcal} / \mathrm{kg}$ commercial diet from Charoend Phokpand. The starter phase used a diet based on (Leeson and Summer 2005). Each diet was treated with enzymes and non-enzymes. This study used $0.5 \mathrm{~g} / \mathrm{kg}$ of diet protease enzyme with a concentration of 12500 Hemoglobin Unit (HUT)/Kg. The feed composition and nutrient content of starter phase broilers can be seen in Table 1 and Table 2. 
Table 1. Feed composition of starter phase broilers

\begin{tabular}{lcccc}
\hline Feed composition (\%) & $\begin{array}{c}\text { Basal } \\
\text { CP 22\% }\end{array}$ & $\begin{array}{c}\text { Basal } \\
\text { CP 19.5\% }\end{array}$ & $\begin{array}{c}\text { Jack bean } \\
\text { CP 22\% }\end{array}$ & $\begin{array}{c}\text { Jack bean } \\
\text { CP 19.5\% }\end{array}$ \\
\hline Maize & 50.50 & 55.00 & 48.50 & 52.85 \\
Rice Bran & 10.40 & 10.40 & 8.50 & 9.00 \\
CPO & 2.20 & 2.40 & 2.20 & 2.20 \\
CGM & 8.00 & 3.20 & 7.00 & 3.00 \\
Soybean Meal & 25.90 & 25.90 & 23.70 & 22.80 \\
Autoclave Jack bean Meal & 0.00 & 0.00 & 7.00 & 7.00 \\
Premix & 0.50 & 0.60 & 0.50 & 0.50 \\
$\mathrm{CaCO}_{3}$ & 0.60 & 0.30 & 0.40 & 0.40 \\
DCP & 1.20 & 1.50 & 1.50 & 1.50 \\
L-lysin & 0.50 & 0.50 & 0.50 & 0.50 \\
DL- Methionin & 0.20 & 0.25 & 0.20 & 0.25 \\
\hline Total & 100 & 100 & 100 & 100 \\
\hline Information : CPO = Crude Palm Oil, CGM $=$ Corn Gluten Meal, CaCO $3=$ Calsium Carbonat, & & &
\end{tabular}

Table 2. Nutrient content of broiler chicken feed based on feed composition

\begin{tabular}{lcccc}
\hline Nutrient & Basal & Basal & Jack bean & Jack bean \\
& CP 22\% & CP 19.5\% & CP 22\% & CP 19.5\% \\
\hline Dry Matter (\%) & 98.84 & 99.13 & 98.80 & 99.15 \\
Ash (\%) & 5.34 & 5.33 & 5.28 & 5.29 \\
Crude Protein (\%) & 22.02 & 19.54 & 22.02 & 19.57 \\
Ether extract (\%) & 4.69 & 4.82 & 6.53 & 6.67 \\
Crude fiber (\%) & 4.23 & 4.31 & 4.58 & 4.69 \\
Metabolizable Energy (Kcal/kg) & 3094.35 & 3091.13 & 3095.07 & 3091.17 \\
Calcium (\%) & 1.05 & 1.04 & 1.04 & 1.06 \\
Total Phospor (\%) & 0.55 & 0.59 & 0.57 & 0.56 \\
Available phosphor (\%) & 0.40 & 0.42 & 0.41 & 0.40 \\
Lysin (\%) & 1.30 & 1.27 & 1.33 & 1.28 \\
Methionin (\%) & 0.57 & 0.57 & 0.56 & 0.56 \\
\hline
\end{tabular}

\section{Enzymes}

This study used $12500 \quad \mathrm{HUT} / \mathrm{g}$ (hemoglobin unit per gram) exogenous commercial protease enzymes in powder form. The protease enzyme was extracted from Bacillus lichenciformis. This enzyme is known as Concentrase-P (Canadian Biosystems, 2015). The building block for the protease enzyme was in the form of $\mathrm{CaCO} 3$, and wheat flour, and silicon dioxide.

\section{MATERIALS AND METHODS Digestive Organ Measurement}

After being reared until the starter period, the digestibility and digestive organ of broiler chicken were measured. Broiler chickens were weighed, then slaughtered, and hung on bamboo to drain the blood. The internal organs were separated. Then, the digestive organs were weighed and the intestine length was measured. The duodenum (intestine surrounding the pancreas), jejunum (part of the intestine after the duodenum and ends with a mekkel diverticulum), and ileum (the end of the small intestine before the cecum) were separated.

\section{Experiment Design and Data Analysis}

This study used a factorial completely randomized design (RALF). This study observed protein source material (soybean meal and jack bean), protein level (22\% and $19.5 \%$ ), and enzyme treatment (without 
enzyme and protease enzymes). This study used 3 replications with each replication consists of 2 male broilers. Data were analyzed by Analysis of Variance (ANOVA).

\section{RESULT AND DISCUSSION Digestive Organ}

The addition of jack bean decreased protein levels but the supplementation of protease enzymes did not influence the proventriculus and ventriculus of starter broilers. The addition of protease significantly $(\mathrm{P}<0.05)$ reduced the small intestine weight. There was no interaction between the use of jack bean, protein levels, and the use of the protease enzyme on proventriculus, ventriculus, and small intestine weight. The digestive organ size of starter broilers can be seen in Table 3 .

Between treatments did not show any interaction because the decrease in protein level given was not too large and also the jack bean was only given in small amounts Broiler chickens can tolerate the treatments so that the role of protease enzyme was insignificant. To find out the health status of broiler chickens, the measurement of digestive organs can be carried out. The treatment of jack bean, different protein levels, and protease enzymes in broiler chicken feed did not influence the proventriculus weight. This is due to the working mechanism of proventriculus that is not influenced by protein and protease enzymes.

Table 3. Digestive organ size of starter broilers

\begin{tabular}{|c|c|c|c|c|c|c|}
\hline \multirow[t]{2}{*}{ Material } & \multirow{2}{*}{$\begin{array}{l}\text { Protein } \\
\text { Level } \\
(\%)\end{array}$} & \multicolumn{2}{|c|}{ Enzyme } & \multirow{2}{*}{$\begin{array}{c}\text { Average of } \\
\text { material }\end{array}$} & \multicolumn{2}{|c|}{ Average of CP } \\
\hline & & Non Enzyme & Protease & & & \\
\hline \multicolumn{7}{|c|}{ Proventriculus (\%) } \\
\hline Basal & 22 & $0.67 \pm 0.08$ & $0.63 \pm 0.03$ & $0.67 \pm 0.02$ & $22 \%$ & $0.64 \pm 0.06$ \\
\hline Basal & 19.5 & $0.71 \pm 0.19$ & $0.65 \pm 0.09$ & & & \\
\hline Jack bean & 22 & $0.65 \pm 0.08$ & $0.61 \pm 0.08$ & $0.64 \pm 0.02$ & $19.5 \%$ & $0.64 \pm 0.07$ \\
\hline \multirow[t]{3}{*}{ Jack bean } & 19.5 & $0.67 \pm 0.02$ & $0.64 \pm 0.02$ & & & \\
\hline & Average & $0.67 \pm 0.02$ & $0.64 \pm 0.02$ & & & \\
\hline & \multicolumn{6}{|c|}{ Ventriculus (\%) } \\
\hline Basal & 22 & $3.20 \pm 0.12$ & $3.18 \pm 0.12$ & $3.31 \pm 0.15$ & $22 \%$ & $3.25 \pm 0.35$ \\
\hline Basal & 19.5 & $3.38 \pm 0.42$ & $3.21 \pm 0.22$ & & & \\
\hline Jack bean & 22 & $3.36 \pm 0.53$ & $3.24 \pm 0.54$ & $3.37 \pm 0.09$ & $19.5 \%$ & $3.43 \pm 0.36$ \\
\hline \multirow[t]{2}{*}{ Jack bean } & 19.5 & $3.46 \pm 0.29$ & $3.42 \pm 0.32$ & & & \\
\hline & Average & $3.37 \pm 0.12$ & $3.31 \pm 0.11$ & & & \\
\hline \multicolumn{7}{|c|}{ Small Intestine (\%) } \\
\hline Basal & 22 & $3.72 \pm 0.59$ & $3.58 \pm 0.38$ & $3.75 \pm 0.26$ & $22 \%$ & $3.85 \pm 0.51$ \\
\hline Basal & 19.5 & $3.90 \pm 0.82$ & $3.81 \pm 0.41$ & & & \\
\hline Jack bean & 22 & $4.16 \pm 0.42$ & $3.61 \pm 0.62$ & $3.99 \pm 0.29$ & $19.5 \%$ & $4.09 \pm 0.47$ \\
\hline \multirow[t]{2}{*}{ Jack bean } & 19.5 & $4.27 \pm 0.11$ & $3.95 \pm 0.06$ & & & \\
\hline & Average & $3.99 \pm 0.14 b$ & $3.74 \pm 0.17 \mathrm{a}$ & & & \\
\hline
\end{tabular}

$\mathrm{CP}=$ Crude Protein, different letters in the same row or column indicate significantly different $(\mathrm{P}<0.05)$.

The main function of the proventriculus is to produce digestive enzymes, one of which is pepsin, which plays a role in protein digestion (Sutrisno 2013). All treatments did not influence the ventriculus or gizzard weight because the gizzard is a digestive organ for mechanical digestion. Mechanical digestion is influenced by differences in crude fiber. According to Sumiyati et al. (2003), the high 
crude fiber in the feed will increase gizzard weight because the gizzard is encouraged to work physiologically harder in processing fiber digestion. In this study, each treatment had an iso fiber so that the treatment did not influence the ventriculus or gizzard.

Protease enzymes can reduce the small intestine weight by assisting the protein digestion so that the intestine does not work too hard. A study by Yuan (2008) showed that the weight of the digestive organs of broiler chickens fed with complex enzymes (containing protease) was lower than the control. There was a tendency to show an increase in small intestine weight in starter broilers with low protein level feed or jack bean even though it was statistically insignificant. This was due to over-perform in the digestive process as a result of poor feed quality. According to Mahardhika et al. (2020), the use of jack bean and low protein feed in starter broilers will result in a slightly higher consumption value because the chickens must fulfill the nutrient needed. Zhou et al (1990) and Siri et al. (1992) stated that the digestive organs will be more active in digesting if more feed is consumed.

\section{Small Intestine Weight.}

The jack bean significantly ( $\mathrm{P}<0.05)$ increased the jejunum length, but it could be returned to the same jejunum length as the basal diet by adding the protease enzyme. The decrease in protein level $(19.5 \%)$ in the ratio significantly $(\mathrm{P}<0.01)$ increased the jejunum length but could be improved by adding protease enzyme. The protease enzyme significantly $(\mathrm{P}<0.01)$ decreased the jejunum length. There was no interaction between jack bean, protein level, and protease enzyme on the weight of duodenum, jejunum, ileum, and the length of duodenum and ileum. The small intestine weight and length data can be presented in Table 4.

The use of protease enzyme in the diet significantly $(\mathrm{P}<0.05)$ reduced the ileum weight. This is due to the proper work of digestive organs so that they do not experience swelling or enlargement. The supplementation of protease enzymes in starter broiler chicken feed can increase crude protein digestible and metabolizable energy so that the ileum weight was normal or did not experience enlargement. The function of the ileum is to absorb nutrients in the form of crude protein.

$22 \% \mathrm{CP}$ feed was not significantly different from that of $19.5 \% \mathrm{CP}$ on jejunum size. According to Iskandar (2004), differences in protein content do not influence the length of the duodenum, jejunum, ileum, and cecum of Pelung and native chickens. It was suspected that the decrease in protein levels was relatively low so that the response to the jejunum had not been very visible.

The protease enzymes reduced the protein content from $22 \%$ to $19.5 \%$, and it was able to increase jejunum length to the same value as the basal feed. According to Zhou et al, (1990) nutritional status can modify the digestive tract. Physiological growth of the digestive tract determines the ability of the intestine to utilize nutrients due to enzyme activity (Rovira et al 1994).

The use of jack bean in broiler chicken rations can increase the jejunum length because the jack bean contains a higher trypsin inhibitor than soybean meal. Trypsin inhibitors can interfere with the digestion and absorption of crude protein. In addition to the trypsin content, the jack bean inhibitor also has several other anti-nutrients such as canavaline, kholin, hydrozianine acid, troginelin, and antichimotrypsin, phenols, isoflavones, niacin, saponins (Primawestri and Rustanti, 2014). According to Doss (2011), jack bean contains 378.3 TIU trypsin inhibitors and $82.5 \mathrm{mg} / 100 \mathrm{~g}$ tannins. These anti-nutrients can inhibit the absorption of several nutrients, especially crude protein.

The protease enzyme supplementation can improve the digestibility of crude protein. Enzymes function as biocatalysts to break down the crude protein into easy-to-digest simpler compounds. A study by Yuan (2008) showed that the weight and length of the digestive organs of broiler chickens fed with 
complex enzymes (containing protease) were lower than the control. The duodenum weight without the enzyme supplementation was $0.87 \%$, whereas with complex enzyme supplementation it contains 0.54 to $0.74 \%$ protease. The jejunum weight of control treatment was $1.32 \%$ while in complex enzyme treatment was $0.99-1.20 \%$, the ileum weight of the control was $0.77 \%$ while in complex enzyme was $0.52-0.64 \%$.

Table 4. Intestine weight and length

\begin{tabular}{|c|c|c|c|c|c|c|}
\hline \multirow[t]{2}{*}{ Material } & \multirow{2}{*}{$\begin{array}{c}\text { Protein } \\
\text { Level } \\
(\%)\end{array}$} & \multicolumn{2}{|c|}{ Enzyme } & \multirow{2}{*}{$\begin{array}{c}\text { Average of } \\
\text { material }\end{array}$} & \multicolumn{2}{|c|}{ Average of $\mathrm{CP}$} \\
\hline & & Non-enzyme & Protease & & & \\
\hline \multicolumn{7}{|c|}{ Duodenum weight $(\%)$} \\
\hline Basal & 22 & $0.90 \pm 0.13$ & $0.86 \pm 0.09$ & $0.93 \pm 0.10$ & $22 \%$ & $0.89 \pm 0.12$ \\
\hline Basal & 19.5 & $1.09 \pm 0.35$ & $0.88 \pm 0.10$ & & & \\
\hline Jack bean & 22 & $0.99 \pm 0.14$ & $0.82 \pm 0.07$ & $0.94 \pm 0.08$ & $19.5 \%$ & $0.98 \pm 0.19$ \\
\hline \multirow{3}{*}{ Jack bean } & 19.5 & $1.02 \pm 0.05$ & $0.94 \pm 0.16$ & & & \\
\hline & Average & $0.99 \pm 0.08$ & $0.87 \pm 0.05$ & & & \\
\hline & \multicolumn{6}{|c|}{ Jejunum weight (\%) } \\
\hline Basal & 22 & $1.68 \pm 0.38$ & $1.31 \pm 0.14$ & $1.57 \pm 0.19$ & $22 \%$ & $1.51 \pm 0.25$ \\
\hline Basal & 19.5 & $1.74 \pm 0.33$ & $1.55 \pm 0.21$ & & & \\
\hline Jack bean & 22 & $1.57 \pm 0.04$ & $1.51 \pm 0.22$ & $1.62 \pm 0.09$ & $19.5 \%$ & $1.67 \pm 0.19$ \\
\hline \multirow[t]{3}{*}{ Jack bean } & 19.5 & $1.70 \pm 0.15$ & $1.69 \pm 0.04$ & & & \\
\hline & Average & $1.65 \pm 0.10$ & $1.53 \pm 0.16$ & & & \\
\hline & \multicolumn{6}{|c|}{ Ileum weight (\%) } \\
\hline Basal & 22 & $1.45 \pm 0.18$ & $1.36 \pm 0.18$ & $1.43 \pm 0.08$ & $22 \%$ & $1.43 \pm 0.22$ \\
\hline Basal & 19.5 & $1.54 \pm 0.25$ & $1.38 \pm 0.11$ & & & \\
\hline Jack bean & 22 & $1.67 \pm 0.17$ & $1.24 \pm 0.21$ & $1.43 \pm 0.18$ & $19.5 \%$ & $1.44 \pm 0.16$ \\
\hline \multirow[t]{2}{*}{ Jack bean } & 19.5 & $1.43 \pm 0.19$ & $1.40 \pm 0.14$ & & & \\
\hline & Average & $1.52 \pm 0.11 \mathrm{~b}$ & $1.35 \pm 0.08 \mathrm{a}$ & & & \\
\hline \multicolumn{7}{|c|}{ Duodenum length $(\mathrm{cm} / 100 \mathrm{~g})$} \\
\hline Basal & 22 & $6.77 \pm 0.74$ & $6.70 \pm 0.68$ & $7.32 \pm 0.68$ & $22 \%$ & $7.28 \pm 1.26$ \\
\hline Basal & 19.5 & $8.21 \pm 1.13$ & $7.53 \pm 0.55$ & & & \\
\hline Jack bean & 22 & $8.28 \pm 1.73$ & $7.28 \pm 1.58$ & $7.87 \pm 0.51$ & $19.5 \%$ & $7.91 \pm 0.83$ \\
\hline \multirow[t]{2}{*}{ Jack bean } & 19.5 & $8.29 \pm 0.19$ & $7.62 \pm 1.19$ & & & \\
\hline & Average & $7.89 \pm 0.75$ & $7.31 \pm 0.37$ & & & \\
\hline \multicolumn{7}{|c|}{ Jejunum length $(\mathrm{cm} / 100 \mathrm{~g})$} \\
\hline Basal & 22 & $17.72 \pm 0.51$ & $16.10 \pm 1.41$ & $7.05 \pm 0.82 \mathrm{a}$ & $22 \%$ & $16.72 \pm 1.20 \mathrm{~A}$ \\
\hline Basal & 19.5 & $17.75 \pm 0.50$ & $16.63 \pm 0.41$ & & & \\
\hline Jack bean & 22 & $17.32 \pm 15.74$ & $15.74 \pm 0.14$ & $18.03 \pm 1.96 b$ & $19.5 \%$ & $18.35 \pm 1.68 \mathrm{~B}$ \\
\hline \multirow[t]{2}{*}{ Jack bean } & 19.5 & $20.32 \pm 1.16$ & $18.74 \pm 1.66$ & & & \\
\hline & Average & $18.02 \pm 0.82 \mathrm{~A}$ & $17.05 \pm 0.82 \mathrm{~B}$ & & & \\
\hline \multicolumn{7}{|c|}{ Ileum length $(\mathrm{cm} / 100 \mathrm{~g})$} \\
\hline ' & 22 & $18.36 \pm 1.47$ & $17.19 \pm 1.22$ & $18.50 \pm 0.99$ & $22 \%$ & $18.07 \pm 1.95$ \\
\hline Basal & 19.5 & $19.49 \pm 0.72$ & $18.72 \pm 2.99$ & & & \\
\hline Koro & 22 & $19.02 \pm 2.37$ & $17.72 \pm 2.99$ & $19.07 \pm 0.79$ & $19.5 \%$ & $19.48 \pm 1.57$ \\
\hline \multirow[t]{2}{*}{ Koro } & 19.5 & $20.77 \pm 0.25$ & $18.73 \pm 2.99$ & & & \\
\hline & Average & $19.41 \pm 1.01$ & $18.15 \pm 0.83$ & & & \\
\hline
\end{tabular}

$\mathrm{CP}=$ Crude Protein, different letters in the same row or column indicate significant differences $(\mathrm{P}<0.05)$, and capital letters indicate significant differences $(\mathrm{P}<0.01)$ 


\section{CONCLUSIONS}

The decrease in protein level to $19.5 \%$ and the use of jack bean (Canavalia ensiformis) increased the size of the digestive organs of starter phase Broiler chickens. The use of protease enzymes can reduce the small intestine weight, ileum weight, and jejunum length.

\section{REFERENCES}

Canadian Bio System. (2015). Concentrase$P$. https://canadianbio.com/EnzymeSupplements

Doss, A., Pugalenthi, M., Vadivel, V. G., Subhashini, G., \& Anitha Subash, R. (2011). Effects of processing technique on the nutritional composition and antinutrients content of under-utilized food legume Canavalia ensiformis L.DC. International Food Research Journal, 18(3), 965-970.

Iskandar, S. (2004). Respon pertumbuhan dan perkembangan alat pencernaan ayam anak silangan pelung $\mathrm{x}$ kampung terhadap kandungan protein ransum. Jitv, 9(4), 217-225.

KEMENDAG. (2017). Perkembangan Impor Menurut HS 6 Digit Periode: 20122017. http://www.kemendag.go.id/id/ economicprofile/indonesia-exportimpo rt/importgrowth-hs-6-digits.\%0A

Leeson, S., \& Summers, J. D. (2005). Commercial Poultry Nutrition (3rd ed.). Nottingham University Press.

Maradon, G. G., Sutrisna, R., \& Erwanto. (2015). Pengaruh ransum dengan kadar serat kasar berbeda terhadap organ dalam ayam jantan tipe medium umur 8 minggu. Jurnal Ilmiah Peternakan Terpadu, 3(2), 6-11.

Primawestri, M. A., \& Rustanti, N. (2014). Pengaruh pemberian susu koro pedang (Canavalia ensiformis) terhadap kadar kolesterol total dan trigliserida serum tikus sprague dawley hiperkolesterolemia. Journal of Nutrition College, 3(4), 447-455. https://doi.org/10.14710/jnc.v3i4.6826

Resnawati, H. (2002). Produksi karkas dan organ dalam ayam pedaging yang diberi ransum mengandung tepung cacing tanah (Lumbricus rubbellus). Seminar Nasional Teknologi Peternakan Dan Veteriner.

Rosyani, S. (2013). Pemberian Pakan Konsentrat Mengandung Tepung Inti Sawit yang Ditambahkan Pollard atau Dedak dan Pengaruhnya terhadap Persentase Organ Dalam Ayam Broiler. Institut Pertanian Bogo.

Rovira, N., Soriano M, E., \& Planas J, M. (1994). Ontogenic and regional changes in kinetic constants of methyl-D-glucoside transport in chicken small intestine. Biochem. Biochem. Soc. Trans, 22(262).

Siri, S., Tobioka, H., \& Tasaki, I. (1992). Effects of dietary fibers on growth performance, development of internal organs, protein and energy utilization, and lipid content of growing chicks. Japanese Poultry Science, 29(2), 106114. https://doi.org/10.2141/jpsa.29.106

Sutrisno, Yunianto, \& Suthama. (2016). Persentase berat karkas dan organ dalam ayam broiler yang diberi tepung daun talas (Colocasia Esculenta (L.) Schott) dalam ransumnya. Media Peternakan, 26(1), 48-60.

Yuan, J., Yao, J., Yang, F., Yang, X., Wan, X., Han, J., Wang, Y., Chen, X., Liu, Y., Zhou, Z., Zhou, N., \& Feng, X. (2008). Effects of supplementing different levels of a commercial enzyme complex on performance, nutrient availability, enzyme activity and gut morphology of broilers. Asian-Australasian Journal of Animal Sciences, 21(5), 692-700. https://doi. org/10.5713/ajas.2008.70375

Zhou, Z. -X., Isshiki, Y., Yamauchi, K., \& Nakahiro, Y. (1990). Effects of forcefeeding and dietary cereals on gastrointestinal size, intestinal absorptive ability and endogenous nitrogen in ducks. British Poultry Science, 31(2), 307-317. https://doi. org/10.1080/00071669008417261 